\title{
The identification and differentiation of the Candida parapsilosis complex species by polymerase chain reaction-restriction fragment length polymorphism of the internal transcribed spacer region of the rDNA
}

\author{
Leonardo Silva Barbedo $/{ }^{+}$, Maria Helena Galdino Figueiredo-Carvalho, \\ Mauro de Medeiros Muniz, Rosely Maria Zancopé-Oliveira
}

Fundação Oswaldo Cruz, Instituto Nacional de Infectologia Evandro Chagas, Laboratório de Micologia, Rio de Janeiro, RJ, Brasil

Currently, it is accepted that there are three species that were formerly grouped under Candida parapsilosis: C. parapsilosis sensu stricto, Candida orthopsilosis, and Candida metapsilosis. In fact, the antifungal susceptibility profiles and distinct virulence attributes demonstrate the differences in these nosocomial pathogens. An accurate, fast, and economical identification of fungal species has been the main goal in mycology. In the present study, we searched sequences that were available in the GenBank database in order to identify the complete sequence for the internal transcribed spacer (ITS)1-5.8S-ITS2 region, which is comprised of the forward and reverse primers ITS1 and ITS4. Subsequently, an in silico polymerase chain reaction-restriction fragment length polymorphism (PCR-RFLP) was performed to differentiate the C. parapsilosis complex species. Ninety-eight clinical isolates from patients with fungaemia were submitted for analysis, where 59 isolates were identified as C. parapsilosis sensu stricto, 37 were identified as C. orthopsilosis, and two were identified as C. metapsilosis. PCR-RFLP quickly and accurately identified C. parapsilosis complex species, making this method an alternative and routine identification system for use in clinical mycology laboratories.

Key words: Candida parapsilosis complex - PCR-RFLP - fungaemia

The incidence of fungaemia, i.e., candidaemia, keeps increasing steadily (Aittakorpi et al. 2012), especially in hospitalised immunocompromised patients (Takuma et al. 2015). While Candida spp are the third or fourth most common causative agents of fungaemia (Cantey \& Milstone 2015), Candida parapsilosis oscillates between the second and fourth most common agent of candidaemia in hospitals throughout the United States of America (Wisplinghoff et al. 2014), Europe (Cobos-Trigueros et al. 2014), Asia (Wu et al. 2014), and Latin America (Nucci et al. 2013). C. parapsilosis has been associated with either localised or deep-seated infections (Trofa et al. 2008). Candidaemia caused by C. parapsilosis is generally related to the presence of a central venous catheter ( $\mathrm{Hu}$ et al. 2014), as well as the use of parenteral nutrition (Hirai et al. 2014), and C. parapsilosis is the predominant species that causes bloodstream infections in premature newborns in neonatal intensive unit care (Pammi et al. 2014).

Currently, it is accepted that there are three species that were formerly grouped under $C$. parapsilosis: $C$. parapsilosis sensu stricto, Candida orthopsilosis, and Candida metapsilosis (Tavanti et al. 2005). In fact, characteristics such as the antifungal susceptibility profile

doi: 10.1590/0074-02760150466

Financial support: CNPq (350338/2000-0), FAPERJ (E-

26/103.157/2011) (to RMZ-O, in part)

+Corresponding author: leonardo.barbedo@ini.fiocruz.br

Received 22 December 2015

Accepted 1 March 2016
(Bonfietti et al. 2012, Ruiz et al. 2013, Figueiredo-Carvalho et al. 2014), virulence attributes, as shown in human oral and epidermal tissues models (Gácser et al. 2007), the ability to produce extracellular proteases, lipase secretion, pseudohyphae formation (Németh et al. 2013), differences in biofilm biomass (Lattif et al. 2010), and the ability to cause tissue damage in the nonconventional host Galleria mellonella (Gago et al. 2014) have demonstrated the diversity of these species, including isolates recovered from clinically healthy animals (dogs, psittacines, raptors, and a prawn) (Brilhante et al. 2014).

Previous studies have shown that $C$. metapsilosis was associated with a reduced virulence as compared to $C$. orthopsilosis and C. parapsilosis sensu stricto (Orsi et al. 2010). This finding may reflect the decreased ability of C. metapsilosis to adhere to epithelial cells (Bertini et al. 2013). In addition, Constante et al. (2014) have shown that patients with candidaemia caused by $C$. orthopsilosis presented with different predisposing conditions to infection as compared to those infected by $C$. parapsilosis sensu stricto.

An accurate, faster, and economical identification of fungal species has been the main goal in mycology (Alnuaimi et al. 2014), especially when species complexes are involved because identification based on solely phenotypic characteristics is often inconclusive due the variability within the $C$. parapsilosis complex species. Molecular analyses have been used for this purpose, and a single step polymerase chain reaction (PCR) using a pair of universal primers [internal transcribed spacer (ITS)1 and ITS4] to amplify the ITS1-5.8S-ITS2 of the ribosomal DNA (rDNA) (genes encoding for ribosomal RNA) region has been considered as a barcoding sequence, i.e., the most widely used genetic marker in identifying species (Schoch et al. 2012). Therefore, the 
aim of this study was develop a new and reliable identification strategy to differentiate between the clinical $C$. parapsilosis complex isolates. We developed this strategy in order to correctly identify the species using a PCR associated with double enzymatic digestion [restriction fragment length polymorphism (RFLP)] and compared this method to the analysis of the partial D1/D2 region of the 28S rDNA gene sequences (Barbedo et al. 2015).

The reference strains of $C$. parapsilosis, C. orthopsilosis, and C. metapsilosis that were available in the GenBank database were analysed to identify the complete sequences for the ITS1-5.8S-ITS2 region of the ATCC 22019 strain (C. parapsilosis, from Puerto Rico), the ATCC 96141 strain (C. orthopsilosis, from San Antonio, Texas, USA), and the ATCC 96143 strain (C. metapsilosis, from Livermore, California, USA) under the GenBank accessions AY939798, EU564208, and EU564207, respectively. These regions comprised the forward and reverse primers ITS1 (5'-TCCGTAGGTGAACCTGCGG-3') and ITS4 (5'-TCCTCCGCTTATTGATATGC-3'). In silico PCR amplification using the FastPCR v.6.0 software was performed using the ITS1 and ITS4 primers. The selected sequences were used to determine the length of the products and in silico RFLP was performed using the pDRAW32 DNA analysis software v.1.1.125 database. HhaI and Sau96I were selected based on the presence of cleavage sites that generated fragments that could discriminate between the species complex on a conventional agarose gel. Species-specific variations were thus identified according to the restriction enzyme banding profile. Double digestion with HhaI and Sau96I cut the ITS1-5.8S-ITS2 PCR products of the $C$. parapsilosis complex reference strains in three different molecular patterns, producing 117, 178, and 225 bp fragments for ATCC 22019 (C. parapsilosis), 102, 183, and 225 bp fragments for ATCC 96141 (C. orthopsilosis), and 114, 187, and 228 bp fragments for ATCC 96143 (C. metapsilosis) (Supplementary Figure).

Ninety-eight clinical strains of $C$. parapsilosis lato sensu that were isolated from the bloodstream and catheter of critically ill patients and that were maintained at the Fungal Culture Collection of Evandro Chagas National Institute of Infectious Diseases/Oswaldo Cruz Foundation, Brazil were included in this study, which was approved by the Ethical Committee of the same institution. Information about all isolates (except isolates 83 and 84), including species identification, microsatellite typing of C. parapsilosis sensu stricto, and the sequences of the D1/D2 region of the 28S rDNA gene, have previously been published (Barbedo et al. 2015).

Yeast cells were grown on Sabouraud dextrose agar (Difco, USA) and genomic DNA was extracted using the Gentra $^{\circledR}$ Puregene ${ }^{\circledR}$ Yeast/Bact. Kit (Qiagen ${ }^{\circledR}$, USA) according to the manufacturer's protocol. The DNA concentration was determined with a spectrophotometer (NanoVue Plus ${ }^{\mathrm{TM}}$; GE Healthcare, USA). The sample was run on a $1 \%$ agarose gel at $90 \mathrm{~V}$ for $80 \mathrm{~min}$ using gel electrophoresis and the gel was stained with ethidium bromide $\left(0.5 \mu \mathrm{g} \mathrm{mL}^{-1}\right)$ (Sigma-Aldrich, USA). The integrity of the DNA was analysed under ultraviolet light. DNA was stored at $-20^{\circ} \mathrm{C}$ until future use.
PCR analysis of the ITS1-5.8S-ITS2 region of the rDNA gene was performed using a final volume of 50 $\mu \mathrm{L}$. Each reaction mixture contained $50 \mathrm{ng}$ of DNA, $1 \mathrm{X}$ PCR buffer [10 mM Tris- $\mathrm{HCl}$ (pH 8.4), $50 \mathrm{mM} \mathrm{KCl}, 1.5$ $\mathrm{mM} \mathrm{MgCl}$ (Invitrogen ${ }^{\mathrm{TM}}$ Brazil)], $0.2 \mathrm{mM}$ (each dNTP) dATP, dCTP, dGTP, and dTTP (Invitrogen ${ }^{\text {TM }}$, USA), 2.5 $\mathrm{U}$ recombinant DNA polymerase (Invitrogen ${ }^{\mathrm{TM}}$, Brazil), and $50 \mathrm{ng}$ of each of the forward (ITS1) and reverse (ITS4) primers. The PCR was performed in a Bio-Rad model C 1000 using the following program: initial denaturation at $95^{\circ} \mathrm{C}$ for $5 \mathrm{~min}$, followed by 30 cycles of denaturation for $1 \mathrm{~min}$ at $95^{\circ} \mathrm{C}$, annealing for $1 \mathrm{~min}$ at $55^{\circ} \mathrm{C}$, extension for $1 \mathrm{~min}$ at $72^{\circ} \mathrm{C}$, and a final extension step at $72^{\circ} \mathrm{C}$ for $5 \mathrm{~min}$. The PCR products $(25 \mu \mathrm{L})$ were double digested with Sau96I (10 U/ $\mu \mathrm{L})$ and $H h a \mathrm{I}(20 \mathrm{U} / \mu \mathrm{L})$ for $3 \mathrm{~h}$ at $37^{\circ} \mathrm{C}$, and the digested products were mixed with 0.2 volumes of loading buffer and were separated on a $3 \%$ agarose gel at $100 \mathrm{~V}$ using gel electrophoresis for approximately $2 \mathrm{~h}$. After staining with ethidium bromide $\left(0.5 \mu \mathrm{g} \mathrm{mL}^{-1}\right)$, the RFLP patterns were assigned visually based on the fragments obtained on the ATCC strains banding profiles on electrophoresis.

All 98 clinical isolates were identified molecularly using PCR-RFLP, and 59 isolates were identified as $C$. parapsilosis sensu stricto, 37 were identified as $C$. orthopsilosis, and two were identified as C. metapsilosis (Figure). These results are in agreement with the DNA sequencing results of the D1/D2 region of the 28S rDNA gene that were previously described (Barbedo et al. 2015).

The emergence of new species of Candida as potential pathogens is a reflection of changing scenarios in medicine since the 1960s (Giri \& Kindo 2012). C. parapsilosis emerged in recent decades across the globe as an important

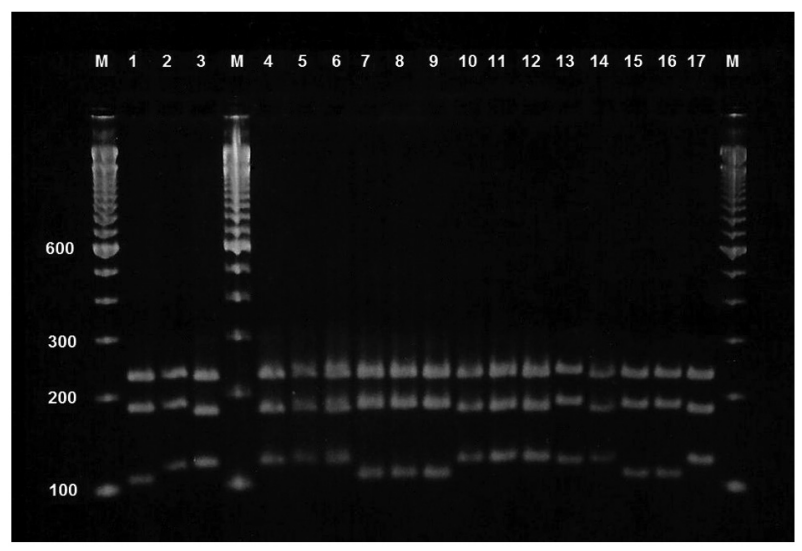

Representative agarose (3\%) gel electrophoresis (at $100 \mathrm{~V}$ for approximately $2 \mathrm{~h}$ ) of restriction digestion of internal transcribed spacer (ITS)1-5.8S-ITS2 region of the ribosomal DNA amplicons (with the primers ITS1 and ITS4) with HhaI and Sau96I from reference strains and 14 selected Candida parapsilosis sensu lato strains. Lane M: 100 bp DNA ladder; 1: Candida orthopsilosis ATCC 96141; 2: Candida metapsilosis ATCC 96143; 3: C. parapsilosis sensu stricto ATCC 22019. The restriction fragment length polymorphism patterns in lanes 4-6, 10-12, 14, and 17 were classified as C. parapsilosis sensu stricto; 7-9, 15, and 16 were classified as C. orthopsilosis, whilst in 13 was classified as $C$. metapsilosis. The positions of migration of the fragments 100, 200, 300, and $600 \mathrm{bp}$ are indicated. 
nosocomial pathogen in invasive fungal infections with haematogenous dissemination (Costa et al. 2014). Since 2005 , based on multilocus sequence typing, the pathogen has been considered to be a C. parapsilosis complex (Tavanti et al. 2005). Morphological and biochemical identification methods are time-consuming, require trained experts, and, in most cases, do not differentiate between the species involved in the complexes (Irinyi et al. 2015).

Alternatively, various molecular methodologies, including PCR-RFLP, have been used for rapid identification, offering a practical approach to identifying species that are most demanding in terms of taxonomic expertise. PCR-RFLP of partial regions of different genes (SADH, $I G S 1$, and $F K S 1$ ) with only one restriction enzyme (BanI, NlaIII, RsaI, HinfI, and EcoRI) has been described to be able to differentiate between the $C$. parapsilosis complex species (Asadzadeh et al. 2009, Mohammadi et al. 2015). However, there were contradictory results regarding two strains on the amplification of a FKS1 region followed by an EcoRI digestion, as well as a $S A D H$ region followed by BamI digestion (Abi-Chacra et al. 2013).

Here, we describe the assessment of the different molecular patterns within the C. parapsilosis complex using only one-step PCR of the ITS1-5.8S- ITS2 rDNA region associated with the best choice of restriction enzymes according to in silico and in vitro analyses. The PCR-RFLP profiles were informative and generated distinct banding patterns for each species, allowing their differentiation. Double digestion with $\mathrm{HhaI}$ and Sau96I produced three fragments: $C$. orthopsilosis was better differentiated by the third fragment (102 bp), which was smaller in size compared to the fragments for C. parapsilosis sensu stricto and C. metapsilosis. On the other hand, the second fragment (187 bp) in C. metapsilosis is above the $C$. parapsilosis sensu stricto fragment. This proposed identification technique for comparing reference strains and clinical isolates is simple, reliable, faster, more affordable, and requires less technical expertise than sequencing.

Because of the heterogeneity in the ITS region of rDNA for each of the C. parapsilosis complex species, studies have also suggested high genetic variability among clinical $C$. orthopsilosis isolates compared to $C$. parapsilosis sensu stricto isolates, which are predominantly clonal and exhibit limited genotypic variations (Merseguel et al. 2015). Asadzadeh et al. (2015) identified three different haplotypes among 19 C. orthopsilosis isolates based on the DNA sequence data of the ITS region and the divergent nucleotides at the 58, 78, 79, 109, $142,143,144,145$, and 414 positions. However, this study found that Sau96I and HhaI double digestion (positions $102 / 103$ and $285 / 286$, respectively) did not cleave in the same divergent nucleotide position previously described within the ITS region, supporting the use of this method.

Different molecular methodologies have been used to identify other Candida yeasts species involved in complexes, e.g., Candida glabrata, Candida bracarensis, and Candida nivariensis (Enache-Angoulvant et al. 2011), Candida haemulonii, C. haemulonii var. vulnera and Candida duobushaemuloniii (Cendejas-Bueno et al. 2012), Candida guilliermondii, Candida fermentati, and Candida carpophila (Medeiros et al. 2007), and Candida rugosa sensu stricto, Candida pseudorugosa, Candida neorugosa, and
Candida mesorugosa (Padovan et al. 2013). rDNA is a common target in PCR-based molecular methods to identify Candida at the species level. PCR techniques using primers that span highly variable sequences within ITS1 and ITS2 and the conserved regions of the $18 \mathrm{~S}, 5.8 \mathrm{~S}$ and 28S rDNA genes have been used to differentiate medically important Candida species (Alnuaimi et al. 2014).

In conclusion, PCR-RFLP for the ITS-rDNA region allowed us to identify $C$. parapsilosis complex species quickly and accurately. This method provides an alternative routine identification system for use in clinical mycology laboratories because only single pair of primers and simple equipment are necessary. There are five important points demonstrating the relevance of this work: (i) this method can be completed in one PCR step, (ii) the use of universal primers (ITS1-5.8S-ITS2) is a more affordable approach (iii) the target of an important sequence (considered to be a barcoding sequence), (iv) using restriction enzymes corroborated by in silico and in vitro analyses gives robustness in our study with $100 \%$ success in comparison with other assays, and (v) the assay is not time-consuming. This is a fairly important aspect especially for hospitalised patients, where speciation is becoming relevant for the early identification and appropriate antifungal therapy for these patients.

\section{REFERENCES}

Abi-Chacra EA, Souza LOP, Cruz LP, Braga-Silva LA, Gonçalves DS, Sodré CL, Ribeiro MD, Seabra SH, Figueiredo-Carvalho MHG, Barbedo LS, Zancopé-Oliveira RM, Ziccardi M, Santos ALS 2013. Phenotypical properties associated with virulence from clinical isolates belonging to the Candida parapsilosis complex. FEMS Yeast Res 13: 831-848.

Aittakorpi A, Kuusela P, Koukila-Kähkölä P, Vaara M, Petrou M, Gant V, Mäki M 2012. Accurate and rapid identification of Candida spp frequently associated with fungemia by using PCR and the microarray-based prove-it sepsis assay. J Clin Microbiol 50: 3635-3640.

Alnuaimi AD, Wiesenfeld D, O’Brien-Simpson NM, Reynolds EC, Peng B, McCullough MJ 2014. The development and validation of a rapid genetic method for species identification and genotyping of medically important fungal pathogens using high-resolution melting curve analysis. Mol Oral Microbiol 29: 117-130.

Asadzadeh M, Ahmad S, Al-Sweih N, Khan ZU 2009. Rapid molecular differentiation and genotypic heterogeneity among Candida parapsilosis and Candida orthopsilosis strains isolated from clinical specimens in Kuwait. J Med Microbiol 58: 745-752.

Asadzadeh M, Ahmad S, Hagen F, Meis JF, Al-Sweih N, Khan Z 2015. Simple, low-cost detection of Candida parapsilosis complex isolates and molecular fingerprinting of Candida orthopsilosis strains in Kuwait by ITS region sequencing and amplified fragment length polymorphism analysis. PLOS ONE 10: e0142880.

Barbedo LS, Vaz C, Pais C, Figueiredo-Carvalho MHG, Muniz MM, Zancopé-Oliveira RM, Sampaio P 2015. Different scenarios for Candida parapsilosis fungaemia revel high numbers of mixed C. parapsilosis and Candida orthopsilosis infections. J Med Microbiol 64: 7-17.

Bertini A, De Bernardis F, Hensgens LA, Sandini S, Senesi S, Tavanti A 2013. Comparison of Candida parapsilosis, Candida orthopsilosis, and Candida metapsilosis adhesive properties and pathogenicity. Int J Med Microbiol 303: 98-103.

Bonfietti LX, Martins MA, Szeszs MW, Pukiskas SB, Purisco SU, Pimentel FC, Pereira GH, Silva DC, Oliveira L, Melhem MS 2012. Prevalence, distribution, and antifungal susceptibility profiles of 
Candida parapsilosis, Candida orthopsilosis, and Candida metapsilosis bloodstream isolates. J Med Microbiol 61: 1003-1008.

Brilhante RSN, Rodrigues TJS, Castelo-Branco DSCM, Teixeira CEC, Macedo RM, Bandeira SP, Alencar LP, Monteiro AJ, Cordeiro RA, Bandeira TJPG, Moreira JLB, Sidrim JJC, Rocha MFG 2014. Antifungal susceptibility and virulence atributes of animal-derived isolates of Candida parapsilosis complex. J Med Microbiol 63: 1568-1572.

Cantey JB, Milstone AM 2015. Bloodstream infections: epidemiology and resistance. Clin Perinatol 42: 1-16.

Cendejas-Bueno E, Kolecka A, Alastruey-Izquierdo A, Theeled B, Groenewald M, Kostrzewa M, Cuenca-Estrella M, Gómez-López A, Boekhout T 2012. Reclassification of the Candida haemulonii complex as Candida haemulonii (C. haemulonii group I), C. duobushaemulonii sp. nov. (C. haemulonii group II), and C. haemulonii var. vulnera var. nov.: three multiresistant humam pathogenic yeasts. J Clin Microbiol 50: 3641-3651.

Cobos-Trigueros N, Kaasch AJ, Soriano A, Torres JL, Vergara A, Morata L, Zboromyrsak Y, de la Calle C, Alejo I, Hernández C, Cardozo C, Marco F, del Río A, Almela M, Mensa J, Martínez JA 2014. Time to positivity and detection of growth in anaerobic blood culture vials predict the presence of Candida glabrata in candidemia: a twocenter European cohort study. J Clin Microbiol 52: 3082-3084.

Constante CC, Monteiro AA, Alves SH, Carneiro LC, Machado MM, Severo LC, Park S, Perlin DS, Pasqualotto AC 2014. Different risk factors for candidemia occur for Candida species belonging to the $C$. parapsilosis complex. Med Mycol 52: 403-406.

Costa VG, Quesada RM, Abe AT, Furlaneto-Maia L, Furlaneto MC 2014. Nosocomial bloodstream Candida infections in a tertiary-care hospital in south Brazil: a 4-year survey. Mycopathologia 178: 243-250.

Enache-Angoulvant A, Guitard J, Grenouillet F, Martin T, Durrens P, Fairhead C, Hennequin C 2011. Rapid discrimitation between Candida glabrata, Candida nivariensis, and Candida bracarensis by use of a singleplex PCR. J Clin Microbiol 49: 3375-3379.

Figueiredo-Carvalho MHG, Barbedo LS, Oliveira MME, Brito-Santos F, Almeida-Paes R, Zancopé-Oliveira RM 2014. Comparison of commercial methods and the CLSI broth microdilution to determine the antifungal susceptibility of Candida parapsilosis complex bloodstream isolates from three health institutions in Rio de Janeiro, Brazil. Mycopathologia 178: 27-35.

Gácser A, Schäfer W, Nosanchuk JS, Salomon S, Nosanchuk JD 2007. Virulence of Candida parapsilosis, Candida orthopsilosis, and Candida metapsilosis in reconstituted human tissue models. Fungal Genet Biol 44: 1336-1341.

Gago S, García-Rodas R, Cuesta I, Mallado E, Alastruey-Izquierdo A 2014. Candida parapsilosis, Candida orthopsilosis, and Candida metapsilosis virulence in the non-conventional host Galleria mellonella. Virulence 5: 278-285.

Giri S, Kindo AJ 2012. A review of Candida species causing blood stream infection. Indian J Med Microbiol 30: 270-278.

Hirai Y, Asahata S, Ainoda Y, Goto A, Fugita T, Totsuka K 2014. Nosocomial Candida parapsilosis candidaemia: risk factors, antifungal susceptibility, and outcome. J Hosp Infect 87: 54-58.

Hu B, Du Z, Kang Y, Zang B, Cui W, Qin B, Fang Q, Qiu H, Li J 2014. Catheter-related Candida bloodstream infection in intensive care unit patients: a subgroup analysis of the China-SCAN study. BMC Infect Dis 14: 594.

Irinyi L, Serena C, Garcia-Hermoso D, Arabatzis M, Desnos-Ollivier M, Vu D, Cardinali G, Arthur I, Normand A-C, Giraldo A, Cunha KC, Sandoval-Denis M, Hendrickx M, Nishikaku AS, Melo ASA, Merseguel KB, Khan A, Rocha JAP, Sampaio P, Briones MRS, Ferreira RC, Muniz MM, Castañón-Olivares LR, Estrada-Barcenas D, Cassagne C, Mary C, Duan SY, Kong F, Sun AY, Zeng X, Zhao Z, Gantois N, Botterel F, Robbertse B, Schoch C, Gams W, Ellis D, Halliday C, Chen S, Sorrell TC, Piarroux R, Colombo AL, Pais C, Hoog
S, Zancopé-Oliveira RM, Taylor ML, Toriello C, Soares CMA, Delhaes L, Stubbe D, Dromer F, Ranque S, Guarro J, Cano-Lira JF, Robert V, Velegraki A, Meyer W 2015. International society of human and animal mycology (ISHAM)-ITS reference DNA barcoding database - the quality controlled standard tool for routine identification of human and animal pathogenic fungi. Med Mycol 53: 313-337.

Lattif AA, Mukherjee PK, Chandra J, Swindell K, Lockhart SR, Diekema DJ, Pfaller MA, Ghannoum MA 2010. Characterization of biofilms formed by Candida parapsilosis, C. metapsilosis, and C. orthopsilosis. Int J Med Microbiol 300: 265-270.

Medeiros EAS, Lott TJ, Colombo AL, Godoy P, Coutinho AP, Braga MS, Nucci M, Brandt ME 2007. Evidence for pseudo-outbreak of Candida guilliermondii fungemia in a university hospital in Brazil. J Clin Microbiol 45: 942-947.

Merseguel KB, Nishikaku AS, Rodrigues AM, Padovan AC, Ferreira RC, Melo ASA, Briones MRS, Colombo AL 2015. Genetic diversity of medically important and emerging Candida species causing invasive infection. BMC Infect Dis 15: 57.

Mohammadi R, Badiee P, Badali H, Abastabar M, Safa AH, Hadipour M, Yazdani H, Heshmat F 2015. Use of restriction fragment length polymorphism to identify Candida species related to onychomycosis. Adv Biomed Res 4: 95.

Németh T, Tóth A, Szenzenstein J, Horváth P, Nosanchuk JD, Grózer Z, Tóth R, Papp C, Hamari Z, Vágvölgyi C, Gácser A 2013. Characterization of virulence properties in the $C$. parapsilosis sensu lato species. PLoS ONE 8: e68704.

Nucci M, Queiroz-Telles F, Alvarado-Matute T, Tiraboschu IN, Cortes J, Zurita J, Guzman-Blanco M, Santolaya ME, Thompson L, Sifuentes-Osornio J, Echevarria JI, Colombo AL, Latin American Invasive Mycosis Network 2013. Epidemiology of candidemia in Latin America: a laboratory-based survey. PLOS ONE 8: e59373.

Orsi CF, Colombari B, Blasi E 2010. Candida metapsilosis as the least virulent member of the 'C. parapsilosis' complex. Med Mycol 48: 1024-1033.

Padovan AC, Melo AS, Colombo AL 2013. Systematic review and new insights into the molecular characterization of the Candida rugosa species complex. Fungal Genet Biol 61: 33-41.

Pammi M, Zhong D, Johnson Y, Revell P, Versalovic J 2014. Polymicrobial bloodstream infections in the neonatal intensive care unit are associated with increased mortality: a case-control study. BMC Infect Dis 14: 390.

Ruiz LS, Khouri S, Hahn RC, Silva EG, Oliveira VK, Gandra RF, Paula CR 2013. Candidemia by species of the Candida parapsilosis complex in children's hospital: prevalence, biofilm production and antifungal susceptibility. Mycopathologia 175: 231-239.

Schoch CL, Seifert KA, Huhndorf S, Robert V, Spouge JL, Levesque CA, Chen W, Fungal Barcoding Consortium 2012. Nuclear ribosomal internal transcribed spacer (ITS) region as a universal DNA barcode marker for Fungi. Proc Natl Acad Sci USA 109: 6241-6246.

Takuma T, Shoji H, Niki Y 2015. Terminal-stage prognostic analysis in candidemia. $J$ Infect Chemother 21: 376-380.

Tavanti A, Davidson AD, Gow NAR, Maiden MCJ, Odds FC 2005. Candida orthopsilosis and Candida metapsilosis spp nov. to replace Candida parapsilosis groups II and III. J Clin Microbiol 43: 284-292.

Trofa D, Gácser A, Nosanchuk JD 2008. Candida parapsilosis, an emerging fungal pathogen. Clin Microbiol Rev 21: 606-625.

Wisplinghoff H, Ebbers J, Geurtz L, Stefanik D, Major Y, Edmond MB, Wenzel RP, Seifert H 2014. Nosocomial bloodstream infections due to Candida spp in the USA: species distribution, clinical features and antifungal susceptibilities. Int J Antimicrob Agents 43: 78-81.

Wu Z, Liu Y, Feng X, Liu Y, Wang S, Zhu X, Chen Q, Pan S 2014. Candidemia: incidence rates, type of species, and risk factors at a tertiary care academic hospital in China. Int J Infect Dis 22: 4-8. 